\title{
The Effect of Topical $0.05 \%$ Cyclosporine in the Prevention of Recurrence Following Pterygium Surgery
}

\author{
(D) Ayse Sevgi Karadag, ${ }^{1}$ (D) Emre Guler, ${ }^{2}$ (1) Selim Genc ${ }^{3}$ \\ 1Department of Ophthalmology, Adıyaman University Training and Research Hospital, Adıyaman, Turkey \\ 2Department of Ophthalmology, Turkiye Hospital, Istanbul, Turkey \\ ${ }^{3}$ Prof. Dr. N. Resat Belger Beyoglu Eye Training and Research Hospital, Istanbul, Turkey
}

\begin{abstract}
Objectives: To evaluate the effect of topical cyclosporine A (CsA) (Restasis, Abbvie, Lake Bluff, IL, USA) on recurrence rates and tear metrics after pterygium excision and limbal-conjunctival autografting (LCUA) technique in patients with primary pterygium.

Methods: A total of 60 eyes of 60 patients with primary pterygium who underwent pterygium excision and the LCUA technique were evaluated prospectively. Among them, 30 eyes of 30 patients were treated with topical CsA (Restasis) for 6 months postoperatively (Group I). The remainder of the patients were assigned to Group 2 . The follow-up period was 12 months for each group. The primary outcome measures were a comparison of Schirmer I test and fluorescein tear break-up time (FTBUT) results, the recurrence rate, and postoperative complications.

Results: There were no significant differences in age (mean age of Group I and 2 was $55.0 \pm 9.7$ years and $56.3 \pm 8.9$ years, respectively) or sex between groups ( $>0.05)$. Farmers were the largest group of patients $(40.0 \%)$. Recurrence of pterygium was observed in $5(16.6 \%)$ eyes in Group I and 8 (26.6\%) eyes in Group 2. The recurrence rate was not statistically significant between groups $(p=0.35)$. The complication rate was significantly lower in Group I compared with that of Group $2(p=0.02)$. The average increase in Schirmer I and FTBUT values was significantly higher in Group I than in Group $2(p<0.05)$.

Conclusion: The use of topical CsA did not demonstrate any significant improvement in the recurrence rate of pterygium following LCUA surgery.
\end{abstract}

Keywords: Limbal-conjunctival autograft, pterygium, pterygium recurrence, Schirmer I, topical cyclosporine A

\section{Introduction}

Pterygium is one of the most common ocular surface diseases associated with neovascularization and inflammation ( $I$ ). The major accepted etiology for the disease is the chronic ultraviolet radiation exposure which leads to the secretion of pro-inflammatory cytokines (2). Classically wing-shaped lesion stretches to the center of the cornea and causes irri- tation and visual loss related to the occlusion of visual axis and induced astigmatism (3). The treatment of the disease is still surgical excision of the lesion; however, it has the major drawback of postoperative recurrence (4). Various adjuvant therapies $(5,6)$ or surgical modifications $(7)$ were proposed for the prevention of pterygium recurrence.

Cyclosporine $A(C s A)$ is an immunosuppressive agent

How to cite this article: Karadag AS, Guler E, Genc S. The Effect of Topical 0.05\% Cyclosporine in the Prevention of Recurrence Following Pterygium Surgery. Beyoglu Eye J 2021; 6(3): 185-190.

Address for correspondence: Emre Guler, MD. Turkiye Hastanesi, Goz Hastaliklari Klinigi, İstanbul, Turkey

Phone: +90 5068521220 E-mail: guleremre83@hotmail.com

Submitted Date: November 18, 2020 Accepted Date: May 10, 2021 Available Online Date: September 27, 2021

${ }^{\circledR}$ Copyright 2021 by Beyoglu Eye Training and Research Hospital - Available online at www.beyoglueye.com

OPEN ACCESS This work is licensed under a Creative Commons Attribution-NonCommercial-ShareAlike 4.0 International License. 
that selectively inhibits T-helper cells and prohibits the expression of pro-inflammatory cytokines (8). In addition, it has been shown to inhibit angiogenesis against the vascular endothelial growth factor (VEGF) (8, 9). Topical CsA has been approved for the treatment of dry eye syndrome (DES), however, it is used for a variety of ocular conditions such as vernal keratoconjunctivitis (10), corneal transplants (II), corneal ulcers (I2), and herpetic stromal keratitis (I3). Several recent reports have shown that clinical use of CsA inhibits pterygium recurrence after surgery due to its inhibitory effect on migration of pterygium fibroblast and expression of matrix metalloproteinases (14-18).

Various methods are available for the investigation of DES. Among these Schirmer test or fluorescein break uptake time (FTBUT) have been used in several studies to investigate the relationship between pterygium and DES with conflicting results. In this study, we investigated the effectiveness of topical CsA on the patients who underwent pterygium excision with limbal-conjunctival autografting (LCAU) and then compare the incidence of recurrence in pterygium after the surgery for the treatment and control groups.

\section{Methods}

In this prospective study, 60 eyes of 60 patients with primary pterygium who underwent pterygium excision using the LCAU technique were included in the study. The patients were randomly divided into two groups (Group I and Group 2 ), both including 30 eyes of 30 patients. All the included patients had primary nasal pterygium exceeding $2 \mathrm{~mm}$ (the lesion was measured horizontally from limbus to cornea with slit-lamp examination), ocular irritation resistant to medical treatment, and decreased visual acuity associated to the pterygium. Exclusion criteria were recurrent and atrophic pterygium, topical CsA allergy, history of the lid or ocular diseases, use of systemic or local medication, and pregnancy. One experienced surgeon performed all surgeries (ASK). Under local anesthesia with $0.5 \%$ proparacaine hydrochloride, the pterygium head was removed from the cornea with a scalpel; then, together with Tenon's capsule, the pterygium was dissected with Westcott scissor. In cases of bleeding, cauterization was avoided in order to prevent any damage to the limbal area. Under the supratemporal bulbar conjunctiva, $0.25 \mathrm{ml}$ of normal saline was injected, and a piece of the conjunctiva, equal in size to the bare area left at the site of the excised pterygium, was marked from the limbal region and removed from Tenon's capsule. We performed a superficial circumferential incision $0.5-\mathrm{mm}$ from the superotemporal limbus to include limbal epithelium in the conjunctival graft. This piece of the conjunctiva was then sutured, with a continuous 10/0 nylon suture, to the bare area. The region where the conjunctival autograft was taken from was left for primary healing. All the patients received topical antibiotic (moxifloxacine) four times daily for 2 weeks, and topical steroids (dexamethasone) four times daily for a month. Topical $0.05 \%$ CsA (Restasis ${ }^{\circledR}$, Allergan Pharmaceutical) was given to Group I, with 6-h periods in a day during the postoperative 6 months. In Group 2, patients did not receive CsA.

Pre- and post-operatively, each patient underwent a standard ophthalmological examination that included uncorrected visual acuity, BCVA, intraocular pressure ,and slit-lamp biomicroscopy. In addition, measurement of FTBUT and the Schirmer I test were performed by the same investigator for each patient. The study was conducted in accordance with the ethical standards stated in the Declaration of Helsinki. The study was approved by the Local Ethics Committee of the participating center. All patients were informed about the purpose of the study and provided their consent.

Main outcome measures were the comparison of FTBUT and Schirmer I test results, recurrence rates, and postoperative complications between groups. The lesion was defined as recurrent when the fibrovascular tissue covered the corneal surface higher than I $\mathrm{mm}(3,19)$.

Data were encoded and analyzed using the Statistical Package for Social Sciences (SPSS) software (version 21.0, SPSS, Inc.). The data were not normally distributed, met by the Kolmogorov-Smirnov test $(p<0.05)$. Quantitative data were compared by Mann-Whitney $U$ and Wilcoxon Signed Ranks Test tests. Kaplan-Meier survival analysis was performed to determine the recurrence-free survival time. Chi-square test was used to investigate the categorical data. P-value $<0.05$ were considered to be statistically significant.

\section{Results}

The mean age of Group I and 2 was $55.0 \pm 9.7$ and $56.3 \pm 8.9$ years, respectively $(p=0.54)$. A total of $14(46.6 \%)$ of the patients in the treatment group were male; $16(53.3 \%)$ of the patients in the control group were male $(p=0.45)$. The mean follow-up period for Group I was $11.6 \pm 3.4$ months (range, 8-16) and 12.7 \pm 3.2 months (range, 8-15) for Group $2(p=0.21)$. A total of $24(40.0 \%)$ of the patients included in our study were farmers, 13 of whom were Group I, and the reminder in Group 2. A total of $23(38.3 \%)$ were housewives, 13 (21.6\%) were civil servants.

In Group I, the mean preoperative Schirmer I and FTBUT values were $7.9 \pm 2.6 \mathrm{~mm}$ and $7.7 \pm 2.0 \mathrm{~s}$. At the end of the follow-up period, these were $12.3 \pm 1.9 \mathrm{~mm}$ and $13.7 \pm 1.9$ s, respectively. In Group 2, the mean preoperative Schirmer I and FTBUT values of Group I were $10.6 \pm 2.5 \mathrm{~mm}$ and $10.0 \pm 3.3 \mathrm{~s}$. At the last visit, these were $13.5 \pm 2.8 \mathrm{~mm}$ and $12.9 \pm 3.0 \mathrm{~s}$, respectively. The mean postoperative Schirmer I and FTBUT were not significantly different between groups $(p>0.05)$. However, when pre-and post-operative Schirmer I 
Table I. FBUT and Schirmer I test results within the groups during the follow-up period

\begin{tabular}{|c|c|c|c|}
\hline & tCsA applied & tCsA not applied & p-value \\
\hline & (mean $\pm S D)$ & (mean $\pm S D)$ & \\
\hline FTBUT (second) & & & \\
\hline Preoperative & $7.7 \pm 2.0$ & $10.6 \pm 2.5$ & $<0.01$ \\
\hline Postoperative 12 months & $13.7 \pm 1.9$ & $13.5 \pm 2.8$ & 0.80 \\
\hline Change & $5.9 \pm 1.8$ & $2.9 \pm 2.7$ & $<0.01$ \\
\hline Schirmer I (mm) & & & \\
\hline Preoperative & $7.9 \pm 2.6$ & $10.0 \pm 3.3$ & $<0.01$ \\
\hline Postoperative 12 months & $12.3 \pm 1.9$ & $12.9 \pm 3.0$ & 0.86 \\
\hline Change & $4.4 \pm 1.8$ & $2.9 \pm 3.0$ & 0.02 \\
\hline
\end{tabular}

FTBUT: Fluorescein Tear Break up-take time; SD: Standard deviation; tCsA:Topical cyclosporine A. Mann-Whitney $U$ test was applied. $P<0.05$ indicates statistically significance.

and FTBUT values were compared, the average increase was significantly higher in Group I $(p<0.05)$ (Table I).

In the early postoperative period, all patients in the two groups had symptomatic complaints of ocular pain, photophobia, lacrimation, and sensation of a foreign body in the eye. No adverse effect was observed in patients receiving topical CsA except a mild irritation when the drug was applied. Punctate corneal staining was not detected in Group I. No serious complication has been detected in any of the cases in our study.

The only postoperative complication in our study was Dellen formation. This complication was significantly higher in Group 2 (8 patients, 26.6\%) compared to Group I (2 patients, $6.6 \%)(p=0.02)$. The Dellen formation was healed after treatment with preservative-free eye drops within I week.

The mean recurrence time was $2.40 \pm 1.16$ months in Group I and 3.00 \pm 0.70 months in Group 2. Recurrence of pterygium was observed in 5 (16.6\%) eyes in Group I and 8 (26.6\%) eyes in Group 2. The risk of pterygium recurrence was I.6 times higher in Group 2 than in Group I (OR=I.600, $95 \% \mathrm{Cl}=0.59 \mathrm{I}-4.333)$. However, the difference was not statistically significant between groups $(p=0.57)$.

\section{Discussion}

The treatment for pterygium is surgical excision. Although bare sclera excision is a simple approach, recurrence is the most common complication. However, there is no definitive treatment modality that prevents postoperative recurrence as well as associated complications.

A previous research demonstrated that pterygium is a local deficit of limbus (20). The degradation of the limbal barrier leads to the proliferation of the pterygium onto the cornea (2I). Al Fayez (I9) showed that the recurrence rates were not statistically different between conjunctival and LCAU transplantation, however, LCAU was more efficient in recurrent pterygium. In the current study, we used the LCAU technique, which has been proved to be safe and effective. In our cases, we used continuous sutures for the stabilization of the graft. However, interrupted sutures may provide better graft tension and may result lower recurrence rates but these should be evaluated in future studies.

Adjuvant agents are treatment choices that help to eliminate recurrence after surgery. Mitomycin $C$ (MMC) is the most commonly used adjuvant agent that prevents cellular activity by inhibiting DNA synthesis (6). It has anti-proliferative effect and prevents recurrence of the pterygium. Previous studies showed recurrence rates varying from 3\% to $38 \%$ in primary pterygium when MMC was used intraoperatively (22-25). However, the use of MMC may lead to severe ocular complications including scleral thinning and necrosis, corneal decompensation, and glaucoma $(26,27)$. In our study, the recurrence rates were $16.6 \%$ in Group I and $26.6 \%$ in Group 2. Group I achieved similar recurrence rate to $M M C$ avoiding its ocular side effects.

The CsA is anti-inflammatory drug that has been widely applied topically in ocular surface diseases (10-13). Previously, it has been demonstrated to inhibit the expression of pro-inflammatory cytokines including tumor necrosis factor- $\alpha$ and also prevents angiogenesis associated to VEGF (8, 9). Another study demonstrated that CsA inhibits the migration of fibroblasts in pterygium tissue in terms of blocking the expressions of matrix metalloproteinase- 3 and - 13 (I7). The CsA was fairly effective in the inhibition of fibroblast migration despite the short application period and low dosage. These findings reveal that postoperative topical CsA ad- 
Table 2. Study outcomes reporting topical CsA use after pterygium surgery

\begin{tabular}{|c|c|c|c|c|}
\hline $\begin{array}{l}\text { Study } \\
\text { (year) }\end{array}$ & $\begin{array}{l}\text { Total eyes } \\
\text { (n) }\end{array}$ & $\begin{array}{l}\text { Follow-up time } \\
\text { (months) }\end{array}$ & Primary outcomes & Results \\
\hline $\begin{array}{l}\text { Özülken et al. (26) } \\
(20 \mid 2)\end{array}$ & 26 & 11 & $\begin{array}{l}\text { Recurrence rate, } \\
\text { Complications }\end{array}$ & $\begin{array}{l}\text { The recurrence rates were significantly lower in CsA } \\
\text { group }(23 \%) \text { than control group ( } 46 \%) \\
\text { Complications were significantly lower in the CsA group. }\end{array}$ \\
\hline $\begin{array}{l}\text { Vural et al. (27) } \\
(201 \mathrm{I})\end{array}$ & 18 & 12 & Recurrence rate & $\begin{array}{l}\text { The recurrence rates were significantly lower in CsA } \\
\text { group }(22 \%) \text { than control group }(44 \%)\end{array}$ \\
\hline $\begin{array}{l}\text { qlbáñez et al. ( I8) } \\
(2009)\end{array}$ & 40 & 6 & $\begin{array}{l}\text { Recurrence rate, } \\
\text { Complications }\end{array}$ & $\begin{array}{l}\text { The recurrence rates were significantly lower in CsA } \\
\text { group (7.5\%) than control group (17.5\%) } \\
\text { No patients had postoperative complications in the CsA } \\
\text { group. These occurred in } 10 \text { eyes in the control group. }\end{array}$ \\
\hline $\begin{array}{l}\text { Aydin et al. (28) } \\
(2008)\end{array}$ & 30 & 12 & $\begin{array}{l}\text { Recurrence rate, } \\
\text { Postoperative pain using } \\
\text { the visual analog scale } \\
\text { (VAS), Complications }\end{array}$ & $\begin{array}{l}\text { The recurrence rates were significantly lower in CsA } \\
\text { group (3.4\%) than control group }(17.9 \%) \\
\text { The average VAS was significantly lower in the CsA group } \\
(p=0.034) \\
\text { The ratio of the cases with no complications was } \\
\text { statistically significantly higher in the CsA group } \\
(p=0.017) \text {. }\end{array}$ \\
\hline $\begin{array}{l}\text { Tok et al. (29) } \\
(2008)\end{array}$ & 31 & 12 & Recurrence rate & $\begin{array}{l}\text { The recurrence rates were significantly lower in CsA } \\
\text { group }(12.9 \%) \text { than control group }(45.2 \%)\end{array}$ \\
\hline $\begin{array}{l}\text { Wu et al.(30) } \\
(1999)\end{array}$ & 25 & 10 & Recurrence rate & $\begin{array}{l}\text { The recurrence rates were significantly lower in CsA } \\
\text { group }(5 \%) \text { than control group }(10 \%)\end{array}$ \\
\hline
\end{tabular}

ministration can be effective to avoid recurrences following primary pterygium excision.

Several studies evaluated the use of topical CsA to prevent recurrences following pterygium excision (Table 2) ( 18 , 28-32). In all these studies topical CsA was found to be effective in preventing pterygium recurrence. Among these the effect of topical $0.05 \%$ CsA has been evaluated in patients that underwent the same surgical technique by Aydin et al. (30) They found that the application of topical CsA following LCAU surgery was effective in preventing recurrence, ocular discomfort, and complications. Their recurrence rate was $3.4 \%$. In the current study, the recurrence rate was $26.6 \%$ for LCAU and $16.6 \%$ for LCAU technique + topical $0.05 \%$ CsA. However, different from the previous studies, the recurrence rates were not statistically significant between groups. In addition, no serious complications occurred in any of the patients as well as decreased postoperative recurrence rate.

Although the association between DES and pterygium is unclear, some studies suggested that the alteration of tear film layer may induce the proliferation subconjunctival fibrovascular tissue. Gunduz et al. (13) reported lower Schirmer I and FTBUT results in patients with pterygium than controls and suggested that DES may be associated with the development of pterygium.

In our study, we aimed to evaluate whether the use of topical CsA following pterygium surgery has any effect on
Schirmer I and FTBUT test results which may be the indicators of DES. Postoperatively, these values were not significantly different between groups however, the average increase in these values was significantly higher in Group I. Although the patients treated with topical CsA did not show any significant recurrence rates, topical CsA may help to correct tear film layer irregularities and consequently treats DES following pterygium surgery which contributes to decrement of recurrence rates in addition to its anti-inflammatory effect.

The CsA $0.5 \%$ formulation twice a day dosing was approved for clinical use based on the phase 3 studies. The ocular retention time of this formulation was approximately $2 \mathrm{~h}$ hence a more frequent dosing might be necessary in cases with severe dry eye or ocular surface disorders to control the inflammation more effectively $(33,34)$. In addition, the repeated use of this formulation leads to an increased accumulation of CsA in the conjunctiva, cornea, and lacrimal gland (35). Application of topical CsA $0.05 \%$ at higher than approved dosages (up to 8 times a day) has shown acceptable tolerability and local good efficacy in patients with severe ocular surface diseases (36). Hence, we used a four times a day regimen for CsA rather than the regular, efficient dose as twice a day.

Dellen was the main postoperative complication in the current study. This may be explained by corneal irregularity 
due to decreased Schirmer I results in the early postoperative period. These patients were successfully treated with preservative-free eye drops.

This study has some limitations. First is the small sample size. Second is the short follow-up period. Third is the lack of pterygium size information since higher level of corneal involvement is correlated with higher recurrences. Finally, there was no placebo treatment for Group 2.

In conclusion, topical CsA did not show any significant improvement in the recurrence rate of pterygium following LCAU surgery. Our findings should be evaluated in future prospective studies including a larger population in a long follow-up period.

\section{Disclosures}

Ethics Committee Approval: Adiyaman University Faculty of Medicine Biomedical Research Ethics Committee, protocol number: 2015/I-9, Date: 25/01/2015.

Peer-review: Externally peer-reviewed.

Conflict of Interest: None declared.

Authorship Contributions: Involved in design and conduct of the study (ASK, EG, SG); preparation and review of the study (ASK, EG, SG); data collection (ASK, EG, SG); and statistical analysis (ASK, EG, SG).

\section{References}

I. Coroneo MT, Di Girolamo N, Wakefield D. The pathogenesis of pterygia. Curr Opin Ophthalmol 1999;10:282-8. [CrossRef]

2. Di Girolamo N, Kumar RK, Coroneo MT, Wakefield D. UVB-mediated induction of interleukin- 6 and -8 in pterygia and cultured human pterygium epithelial cells. Invest Ophthalmol Vis Sci 2002;43:3430-7.

3. Mutlu FM, Sobaci G, Tatar T, Yildirim E. A comparative study of recurrent pterygium surgery: limbal conjunctival autograft transplantation versus mitomycin $C$ with conjunctival flap. Ophthalmology 1999;106:8I7-21. [CrossRef]

4. Singh G, Wilson MR, Foster CS. Long-term follow-up study of mitomycin eye drops as adjunctive treatment of pterygia and its comparison with conjunctival autograft transplantation. Cornea 1990;9:33I-4. [CrossRef]

5. Bekibele CO, Baiyeroju AM, Ajayi BG. 5-fluorouracil vs. beta-irradiation in the prevention of pterygium recurrence. Int J Clin Pract 2004;58:920-3. [CrossRef]

6. Oguz H, Basar E, Gurler B. Intraoperative application versus postoperative mitomycin $\mathrm{C}$ eye drops in pterygium surgery. Acta Ophthalmol Scand 1999;77:147-50. [CrossRef]

7. Fernandes M, Sangwan VS, Bansal AK, Gangopadhyay N, Sridhar MS, Garg P, et al. Outcome of pterygium surgery: analysis over 14 years. Eye (Lond) 2005; I 9: I I 82-90. [CrossRef]

8. Strong B, Farley W, Stern ME, Pflugfelder SC. Topical cyclosporine inhibits conjunctival epithelial apoptosis in experimental murine keratoconjunctivitis sicca. Cornea 2005;24:80-5.
9. Pucci N, Novembre E, Cianferoni A, Lombardi E, Bernardini R, Caputo R, et al. Efficacy and safety of cyclosporine eyedrops in vernal keratoconjunctivitis. Ann Allergy Asthma Immunol 2002;89:298-303. [CrossRef]

10. Secchi AG, Tognon MS, Leonardi A. Topical use of cyclosporine in the treatment of vernal keratoconjunctivitis. Am J Ophthalmol 1990; I 1 0:64I-45. [CrossRef]

I I. Zhao JC, Jin XY. Local therapy of corneal allograft rejection with cyclosporine. Am J Ophthalmol 1995; I 19:189-94. [CrossRef]

12. Zhao JC, Jin XY. Immunological analysis and treatment of Mooren's ulcer with cyclosporin A applied topically. Cornea 1993; |2:48|-8. [CrossRef]

13. Gunduz K, Ozdemir O. Topical cyclosporin as an adjunct to topical acyclovir treatment in herpetic stromal keratitis. Ophthalmic Res 1997;29:405-8. [CrossRef]

14. Gum SI, Kim YH, Jung JC, Kim IG, Lee JS, Lee KW, et al. Cyclosporine A inhibits TGF- $\beta 2$-induced myofibroblasts of primary cultured human pterygium fibroblasts. Biochem Biophys Res Commun 2017;482:1 |48-53. [CrossRef]

15. Hwang S, Choi S. A comparative study of topical mitomycin C, cyclosporine, and bevacizumab after primary pterygium surgery. Korean J Ophthalmol 2015;29:375-8I. [CrossRef]

16. Viveiros MM, Kakizaki FY, Hercules LA, Padovani CR, Candeias JM, Schellini SA. In vitro study of cyclosporine A $0.05 \%$ on primary and recurrent pterygium fibroblasts. Int Ophthalmol 2016;36:237-42. [CrossRef]

17. Kim YH, Jung JC, Jung SY, Kim YI, Lee KW, Park YJ. Cyclosporine a downregulates MMP-3 and MMP-I3 expression in cultured pterygium fibroblasts. Cornea 20 I5;34: I 137-43. [CrossRef]

18. Ibanez M, Eugarrios MF, Calderon DI. Topical cyclosporin A and mitomycin $C$ injection as adjunctive therapy for prevention of primary pterygium recurrence. Ophthalmic Surg Lasers Imaging 2009;40:239-44. [CrossRef]

19. Al Fayez MF. Limbal versus conjunctival autograft transplantation for advanced and recurrent pterygium. Ophthalmology 2002; 109:1752-5. [CrossRef]

20. Dushku N, Reid TW. Immunohistochemical evidence that human pterygia originate from an invasion of vimentin-expressing altered limbal epithelial basal cells. Curr Eye Res 1994; 13:47381. [CrossRef]

21. Zhou WP, Zhu YF, Zhang B, Qiu WY, Yao YF. The role of ultraviolet radiation in the pathogenesis of pterygia (Review). Mol Med Rep 2016;14:3-15. [CrossRef]

22. Cano-Parra J, Diaz-Llopis M, Maldonado MJ, Vila E, Menezo JL. Prospective trial of intraoperative mitomycin $\mathrm{C}$ in the treatment of primary pterygium. Br J Ophthalmol 1995;79:439-4I.

23. Manning CA, Kloess PM, Diaz MD, Yee RW. Intraoperative mitomycin in primary pterygium excision. A prospective, randomized trial. Ophthalmology 1997;104:844-8. [CrossRef]

24. Lam DS, Wong AK, Fan DS, Chew S, Kwok PS, Tso MO. Intraoperative mitomycin $C$ to prevent recurrence of pterygium 
after excision: a 30-month follow-up study. Ophthalmology 1998; 105:901-4; discussion 904-5.

25. Panda A, Das GK, Tuli SW, Kumar A. Randomized trial of intraoperative mitomycin $C$ in surgery for pterygium. Am J Ophthalmol 1998; 125:59-63. [CrossRef]

26. Rubinfeld RS, Pfister RR, Stein RM, Foster CS, Martin NF, Stoleru $S$, et al. Serious complications of topical mitomycin-C after pterygium surgery. Ophthalmology 1992;99:1647-54. [CrossRef]

27. Dunn JP, Seamone CD, Ostler HB, Nickel BL, Beallo A. Development of scleral ulceration and calcification after pterygium excision and mitomycin therapy. Am J Ophthalmol 1991; I 12:343-4.

28. Özülken K, Koç M, Ayar O, Hasiripi H. Topical cyclosporine A administration after pterygium surgery. Eur J Ophthalmol 2012;22:S5-10. [CrossRef]

29. Turan-Vural E, Torun-Acar B, Kivanc SA, Acar S. The effect of topical $0.05 \%$ cyclosporine on recurrence following pterygium surgery. Clin Ophthalmol 20I I;5:88I-5. [CrossRef]

30. Aydin A, Karadayi K, Aykan U, Can G, Colakoglu K, Bilge AH. Effectiveness of topical ciclosporin $A$ treatment after excision of primary pterygium and limbal conjunctival autograft. J Fr Ophtalmol 2008;31:699-704. [CrossRef]
31. Yalcin Tok O, Burcu Nurozler A, Ergun G, Akbas Kocaoglu F, Duman S. Topical cyclosporine A in the prevention of pterygium recurrence. Ophthalmologica 2008;222:39I-6.

32. $\mathrm{Wu} \mathrm{H}$, Chen $\mathrm{G}$. Cyclosporine $\mathrm{A}$ and thiotepa in prevention of postoperative recurrence of pterygium. Yan Ke Xue Bao 1999;15:91-2.

33. Holland EJ, Olsen TW, Ketcham JM, Florine C, Krachmer JH, Purcell J, et al. Topical cyclosporin A in the treatment of anterior segment inflammatory disease. Cornea 1993;12:413-9.

34. Acheampong A, Shackleton M, Lam S, Rudewicz P, Tang-Liu D. Cyclosporine distribution into the conjunctiva, cornea, lacrimal gland, and systemic blood following topical dosing of cyclosporine to rabbit, dog, and human eyes. Adv Exp Med Biol 1998;438:100I-4. [CrossRef]

35. Acheampong AA, Shackleton M, Tang-Liu DD, Ding S, Stern ME, Decker R. Distribution of cyclosporin A in ocular tissues after topical administration to albino rabbits and beagle dogs. Curr Eye Res 1999;18:91-103. [CrossRef]

36. Gire Al, Karakus S, Ingrodi SM, Akpek EK. Frequent dosing of topical cyclosporine a for severe ocular surface disease. J Ocul Pharmacol Ther 2016;32:150-4. [CrossRef] 